\title{
A Simple Procedure for the Separation of Viable Blood Cells, Suitable for Long-Term In Vitro Experiments
}

\author{
FEDOR MEDZIHRADSKY, MICHAEL J. MARKS, AND \\ JOAN I. METCALFE \\ Departments of Biological Chemistry and Upiohn Center for Clinical \\ Pharmacology, The University of Michigan Medical Center, \\ Ann Arbor, Michigan 48104
}

Received July 3, 1973; revised August 14, 1973

There are numerous reports in the literature on the separation from blood of leukocytes (e.g., 1-8) and of platelets (e.g., 9, 10). Existing procedures for the separation of the various cell types from the same sample of blood are rather elaborate and require relatively large amounts of blood (e.g., 11-13). In course of our study on the cellular transport of CNS drugs (e.g., 14-16), we became aware of the need for a reliable and simple procedure for the separation of erythrocytes, leukocytes, and platelets from small samples of blood. The procedure should yield cellular fractions with minimum cross contamination by the other blood cells, and supply cells with unchanging viability over prolonged incubation at $37^{\circ}$ in order to allow a variety of in vitro experiments to be carried out. Furthermore, the procedure should render possible the separation of all the three major cell types from the same sample of blood.

In accordance with the above described goals, this paper reports a procedure for the separation, from single samples of human and rat blood, of cellular fractions of erythrocytes, leukocytes, and platelets. Special emphasis was placed on ascertaining the viability and the metabolic capacity of the separated blood cells and on the simplicity of the procedure.

\section{MATERIALS}

Plasmagel, a modified gelatin fluid containing $\mathrm{NaCl}$ and $\mathrm{CaCl}_{2}$ was obtained from HTI Corporation, Buffalo, N. Y. Biochemicals used for the determination of $\mathrm{ATP}^{1}$ were purchased from Boehringer Mannheim

${ }^{1}$ List of abbreviations: ATP $=$ adenosine-5'-triphosphate; $\mathrm{ADP}=$ adenosine-5'diphosphate; EDTA = ethylenediaminetetraacetic acid; Tris = Tris (hydroxymethyl) aminomethane; $\mathrm{NADP}^{+}=$nicotinamide adenine dinucleotide phosphate; $\mathrm{BSA}=$ bovine serum albumin. 
Corporation, New York, N. Y. and Sigma Chemical Company, St. Louis, Mo., respectively. The latter company was also the supplier of ADP and Trypan Blue. All other chemicals used were of reagent grade.

\section{METHODS}

Collection of Blood. Human blood was drawn by venipuncture from healthy male and female volunteers who were not taking any medications. Rat blood was obtained from the venae cavae of lightly anesthetized (diethylether) male, Sprague-Dawley rats, weighing $300 \mathrm{~g}$.

Standard Incubation Medium. If not otherwise indicated, the suspending and incubation medium contained the following final millimolar concentrations: $\mathrm{Na}^{+}, 155.7 ; \mathrm{K}^{+}, 49 ; \mathrm{Mg}^{2+}, 1.2 ; \mathrm{Cl}^{-}, 131.3 ; \mathrm{SO}_{4}{ }^{2-}, 1.2$; $\mathrm{HPO}_{4}{ }^{2-}, 13.3 ; \mathrm{H}_{2} \mathrm{PO}_{4}^{-}, 2.7$; and glucose, 10 . The ionic balance of this medium showed 163 cationic and anionic charges, respectively. In calculating this figure, the additional amounts of $\mathrm{Cl}^{-}$and $\mathrm{Na}^{+}$ions needed

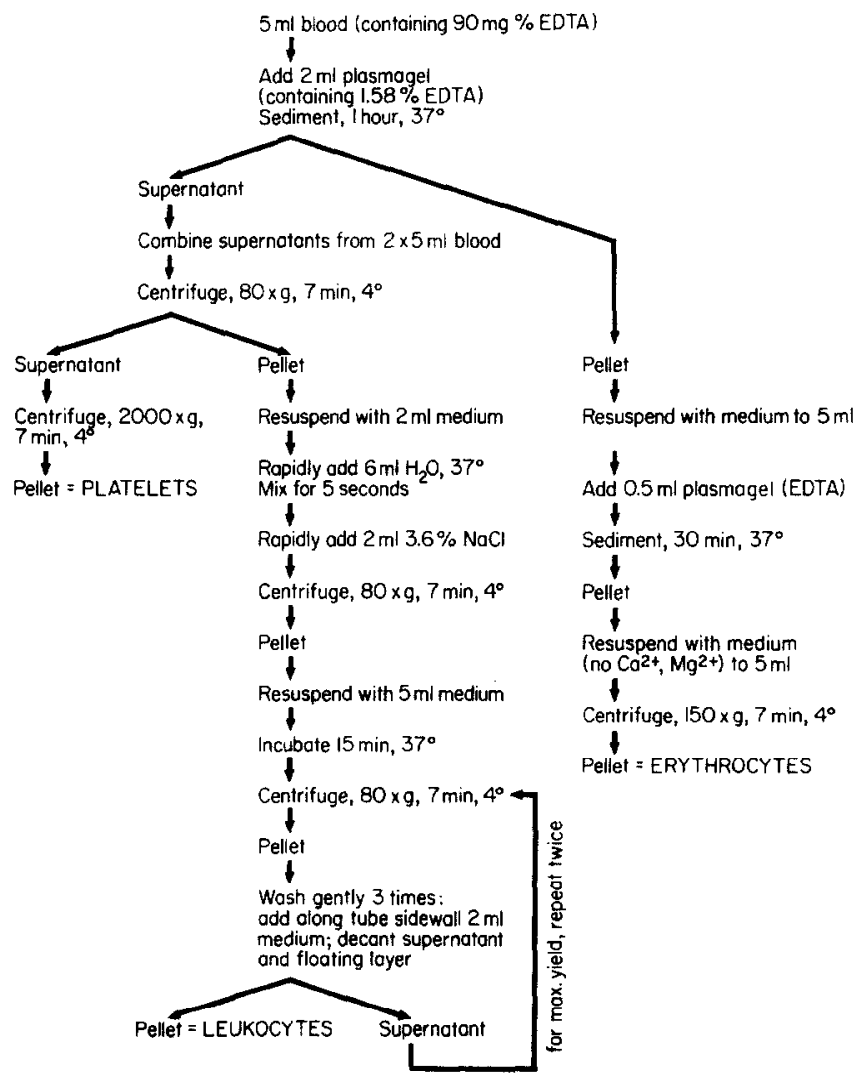

Frg. 1. Scheme for the separation of human blood cells. 
for $\mathrm{pH}$ adjustments have been considered. The medium was prepared as follows: $0.77 \mathrm{M} \mathrm{NaCl}, 200 \mathrm{ml} ; 0.77 \mathrm{M} \mathrm{KCl}, 8 \mathrm{ml} ; 0.77 \mathrm{M} \mathrm{MgSO}_{4}, 2 \mathrm{ml}$; $0.5 \mathrm{M} \mathrm{Na}_{2} \mathrm{HPO}_{4}$ buffer, adjusted to $\mathrm{pH} 7.4$ with $\mathrm{HCl}, 40 \mathrm{ml} ; \mathrm{H}_{2} \mathrm{O}, 1000 \mathrm{ml}$. Glucose, in amounts to give $10 \mathrm{~mm}$ final concentration, was added in solid form to aliquots of the above medium. The $\mathrm{pH}$ of the medium after preparation was approximately 7.3. It was adjusted to $\mathrm{pH} 7.4$ with $\mathrm{NaOH}$.

Separation of Cellular Fractions. Details of the experimental procedures are outlined in Figs. 1 and 2. Throughout the separation, polyethylene tubes were used. After the addition of Plasmagel, the content of the tubes was mixed by inversion.

Yield and Characterization of Cells. The yield of cells was determined both by manual and electronic cell counting. Manual counts and quantitative examination of blood smears were carried out using an $\mathrm{AO}$ Spenser Bright Line hemacytometer. The blood smears were prepared

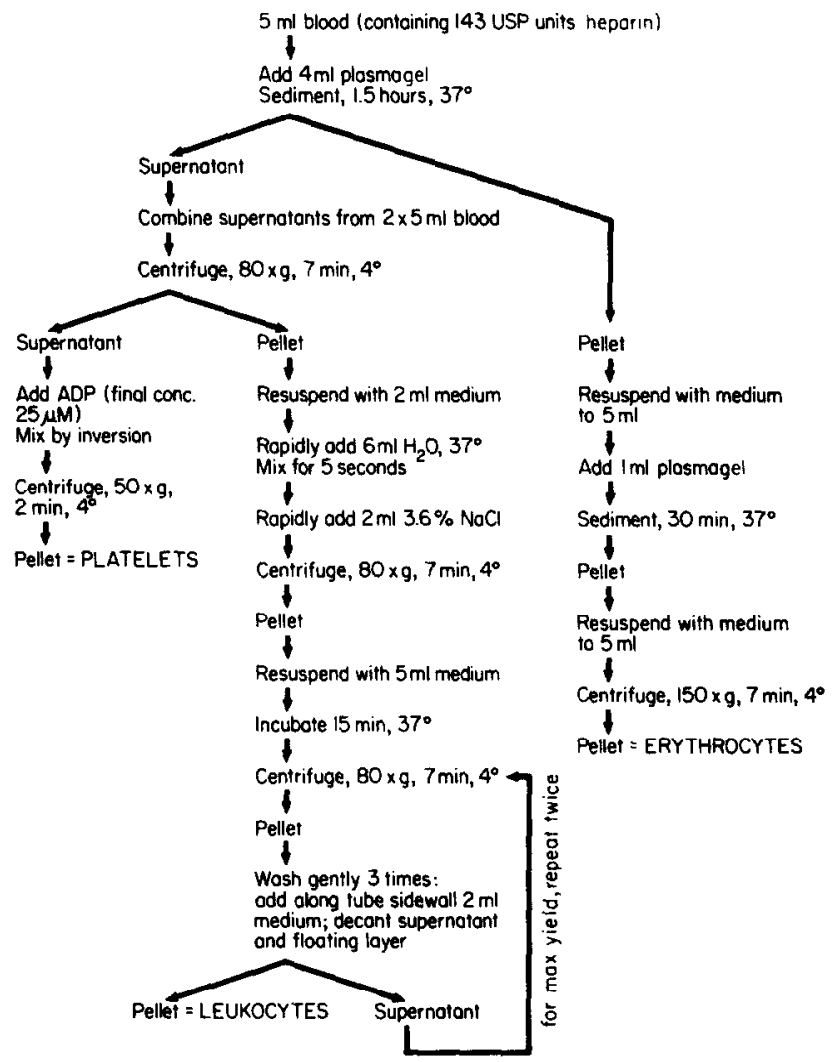

FIG. 2. Scheme for the separation of rat blood cells. 
using Wright's stain (17). Phase contrast microscopic examination of the cellular populations was accomplished with an AO series 10, PhaseStar microscope. Electronic counting was carried out in a Cytograph, model No. 6301 (Bio/Physics Systems, Inc., Mahopac, N. Y.). Using the latter instrument, the cellular fractions were characterized by their size distribution and the results presented as corresponding histograms (Fig. 3). In addition, using the cytograph, differential counts were obtained of viable and injured cells. For that purpose, cell counts were obtained after an incubation of the cells with 0.05\% Trypan Blue for 20 minutes at $37^{\circ}(18,19)$. The number of stained cells was expressed as percent of the total cell count, obtained without prior exposure to the dye.

Protein Determination. The method of Lowry et al. (20) was used. Determination of Cellular Sodium and Potassium Concentrations. Aliquots of the cellular suspensions, representing $1-3 \times 10^{7}$ cells were

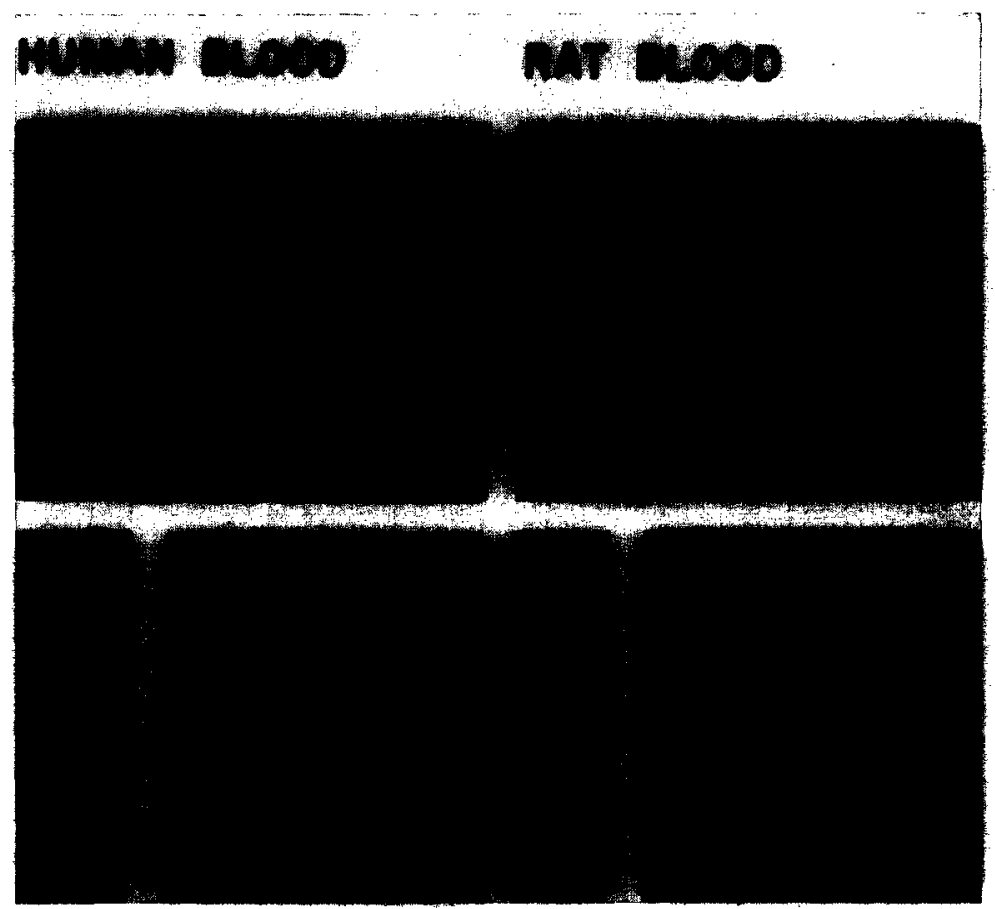

Fic. 3. Histograms of size distribution in various fractions of blood cells. Upper figures: erythrocytes; lower left figures: platelets; lower right figures: leukocytes. The abscissa and ordinate correspond to the cellular diameter and the number of cells of identical size, respectively. The calibration of these coordinates in case of human and of rat blood are not identical. The histograms were generated using a Cytograph, model No. 6301, as described in METHODS. 
centrifuged at $12,000 \mathrm{~g}$ for 3 minutes at $4^{\circ}$. The cells were thoroughly washed with cold $0.25 \mathrm{M}$ sucrose by resuspension and gentle mixing on a Vortex mixer. After renewed centrifugation, the pellets were digested in $50 \mu \mathrm{l}$ of $70 \% \mathrm{HNO}_{3}$ for 2 hours at $60^{\circ}$ (alternatively, 1 hour at $80^{\circ}$ ). After the addition of $5 \mathrm{ml} \mathrm{LiCl} \mathrm{reference} \mathrm{solution} \mathrm{(} 15 \mathrm{mM}$ ), the measurements were carried out in an IL flame photometer.

Determination of Cellular ATP. All the following steps were carried out at $2-4^{\circ}$. Aliquots of the cellular suspension, representing approximately $5 \times 10^{7}$ cells, were centrifuged at $12,000 \mathrm{~g}$ for 3 minutes. The pellets were treated in the plastic centrifuge tubes with $400 \mu \mathrm{l}$ of $0.6 \mathrm{M}$ $\mathrm{HClO}_{4}$, thoroughly mixed with a glass rod and the suspensions transferred to 1-ml all-glass Potter-Elvehjem homogenizers. After homogenization, the suspensions were centrifuged in $4-\mathrm{ml}$ tubes at $2,000 \mathrm{~g}$ for 15 minutes and $250 \mu \mathrm{l}$ of the supernatants were transferred into fresh 4-ml tubes. Following neutralization to $\mathrm{pH} 7.0$ with $2 \mathrm{M} \mathrm{K}_{2} \mathrm{CO}_{3}$, the suspensions were kept in ice for 10 minutes and then centrifuged at $2000 \mathrm{~g}$ for 5 minutes. The clear supernatants were decanted and stored at $-70^{\circ}$ until analysis.

ATP was determined by measuring the fluorescence of NADPH in a coupled enzymatic reaction utilizing hexokinase and glucose-6-phosphate dehydrogenase. The final millimolar concentrations during the assay were: Tris- $\mathrm{HCl}\left(\mathrm{pH} \mathrm{7.5)}, 100 ; \mathrm{MgCl}_{2}, 5\right.$; glucose, 1 ; $\mathrm{NADP}^{+}, 0.05$; as well as BSA, 0.01\%; glucose-6-phosphate dehydrogenase, $2 \mu \mathrm{g} / \mathrm{ml}$; and hexokinase, $4 \mu \mathrm{g} / \mathrm{ml}$. The measurements were carried out in a Farrand filter fluorometer at excitation and emission wavelengths of 360 and $470 \mathrm{~nm}$, respectively. To isolate these wavelengths, Corning glass color filters No. 7-37 (glass No. 5860) and, starting from the photocell side, 3-72 (glass No. 3387), 4-70 (glass No. 4303), 5-61 (glass No. 5562), were used.

Measurement of Oxygen Uptake. The rate of respiration of the cellular suspensions was determined in air at $37^{\circ}$ using an YSI oxygen electrode connected to a recorder. The volume of the measuring chamber was $3 \mathrm{ml}$ and the concentration of cells was $1-5 \times 10^{7}$ cells $/ \mathrm{ml}$ standard incubation medium. The oxygen capacity of 3-ml incubation medium at $37^{\circ}$ was $14.6 \mu \mathrm{l}$.

\section{RESULTS}

Separation of Blood Cells. The principal step in the separation of leukocytes from erythrocytes was a sedimentation in the presence of Plasmagel as described earlier (14). Special attention was required to avoid contamination of the other cellular fractions by platelets. With rat blood, heparin was used as anticoagulant and the platelets were ag- 
gregated with ADP prior to their pelleting by centrifugation (Fig. 2). Human platelets, however, showed different characteristics: it was necessary to replace heparin with EDTA and, in addition, to include quite high concentrations of the latter compound during sedimentation in order to chelate the $\mathrm{Ca}^{2+}$ present in Plasmagel (Fig. 1). The concentration of unbound EDTA during sedimentation was approximately $2 \mathrm{~mm}$. The yield of cells as well as the ratios protein/cell count are summarized in Table 1.

Characterization of the Cellular Fractions. As the size distribution in Fig. 3 shows, there was no evidence for cross contamination in the individual cellular fractions. The two populations visible in the leukocyte fractions correspond to the heterogeneity of these blood cells and to the reversed ratio of granulocytes and lymphocytes in human and rat blood, respectively. The virtual absence of cross contamination shown by cytographic analysis, was confirmed by microscopic examination under phase contrast and by differential manual counts of cells treated with Wright's stain. In all of the latter experiments, the contamination of a particular fraction by any other cell type was less than $5 \%$. The presence of minutc amounts of irrcgularly shaped small fragments was noticcable in the erythrocyte and leukocyte fractions from both human and rat blood. This contamination which, based on protein, in all cases was less than $1 \%$, probably represents protein fragments resulting from some cellular damage which occurred in course of the separation procedure. Strong evidence against a cellular nature of these particles was obtained by the complete staining of the fragments after incubation with Trypan Blue.

For methodological reasons, the uptake of Trypan Blue by erythrocytes was not determined. In all other cellular preparations less than $3 \%$ of the total cells were stained at any time during the 3 -hour incubation at $37^{\circ}$, as determined by both microscopic and electronic differential cell counts.

TABLE 1

Yield of Blood Cells and Protein Equivalent of Cell Counts

\begin{tabular}{|c|c|c|c|c|c|c|}
\hline \multirow{3}{*}{$\frac{\text { Blood cells }}{\text { Erythrocytes }}$} & \multicolumn{4}{|c|}{$\begin{array}{l}\text { Yield of cells per milliliter blood } \\
\text { (Cell number and percent) }\end{array}$} & \multicolumn{2}{|c|}{$\mathrm{mg}$ protein $/ 10^{9}$ cells } \\
\hline & \multicolumn{2}{|c|}{ Human } & \multicolumn{2}{|c|}{ Rat } & Human & Rat \\
\hline & $3.4 \times 10^{\circ}$ & $67 \pm 7 \%$ & $6.0 \times 10^{\circ}$ & $85 \pm 12 \%$ & $33 \pm 7$ & $19 \pm 5$ \\
\hline Leukocytes & $2.1 \times 10^{6}$ & $42 \pm 11 \%$ & $8.5 \times 10^{6}$ & $59 \pm 7 \%$ & $101 \pm 5$ & $67 \pm 11$ \\
\hline Platelets & $1.1 \times 10^{8}$ & $54 \pm 8 \%$ & $3.2 \times 10^{8}$ & $45 \pm 11 \%$ & $7 \pm 2$ & $8 \pm 1$ \\
\hline
\end{tabular}


Sodium and Potassium Content. Erythrocytes and platelets from both human and rat blood showed no change in their content of sodium and potassium during a 3 -hour incubation period at $37^{\circ}$ (Figs. 4 and 5). Whereas the concentration of these monovalent cations did not change significantly in rat leukocytes, a decrease of potassium and a corresponding increase of sodium was noticed after the second hour of incubation in the human white blood cells (Fig. 4). These changes amounted to approximately $10 \%$ of the corresponding initial values.

Cellular ATP Concentration. The mean concentration of ATP in all three cellular fractions from both human (Fig. 6) and rat (Fig. 7) blood did not change during the 3-hour incubation period.

Uptake of Oxygen. For obvious reasons, erythrocytes were excluded from these experiments. Although the oxygen consumption of leukocytes, particularly those from the rat, showed somewhat greater variability when compared to platelets (Figs. 8 and 9), no significant change of the mean respiration rate of both of these cell types occurred during 4 hours of incubation at $37^{\circ}$.

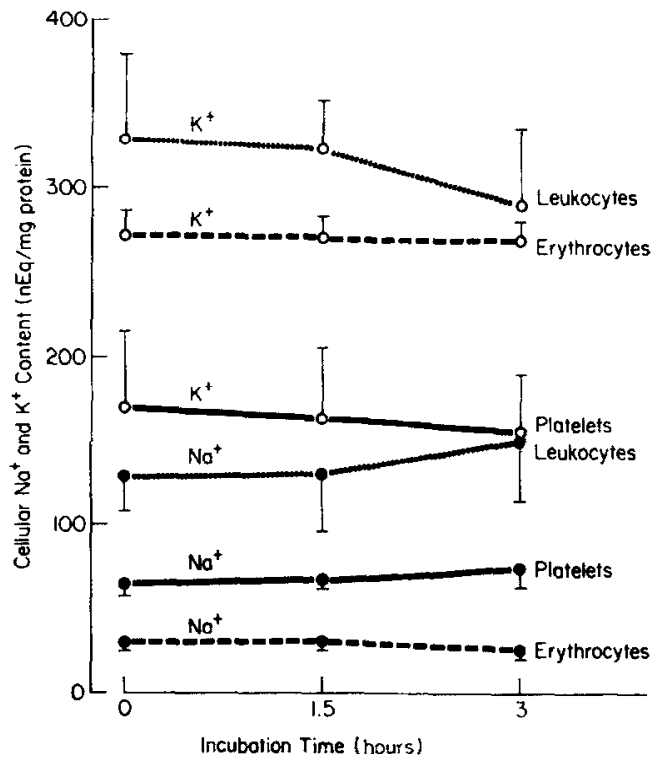

FIG. 4. Sodium and potassium content in human blood cells. Immediately after the isolation, aliquots of the cellular suspensions corresponding to approximately $3 \times 10^{\circ} \mathrm{calls} / \mathrm{ml}$ of standard incubation medium were incubated at $37^{\circ}$ for the times indicated. The further treatment of the cells as well as the measurement of the monovalent cations was as described in METHODS. Presented are means \pm SD of six determinations using different preparations of the particular cells. 


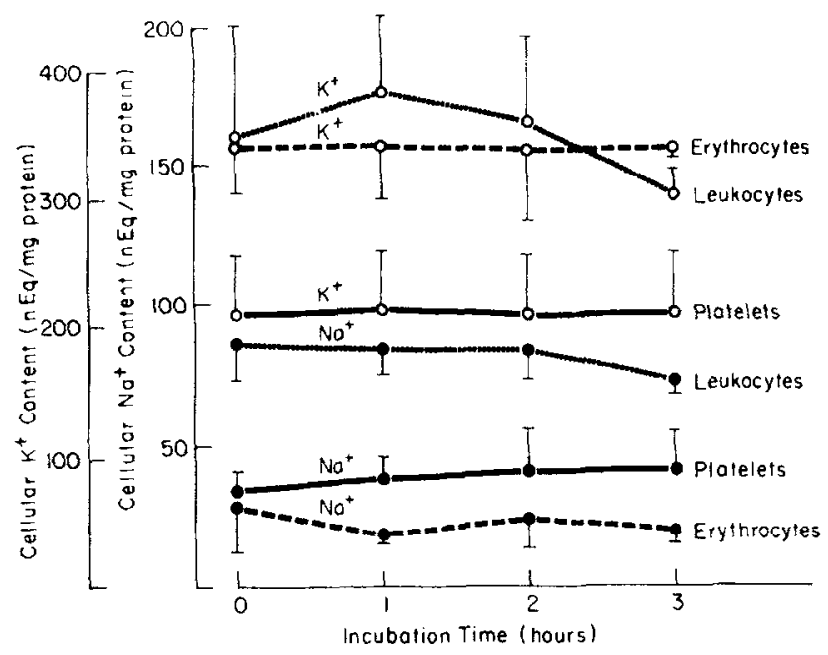

FIG. 5. Sodium and potassium content in rat blood cells. Immediately after the isolation, aliquots of the cellular suspensions corresponding to approximately $3 \times 10^{\text {i }}$ cells $/ \mathrm{ml}$ of standard incubation medium were incubated at $37^{\circ}$ for the times indicated. The further treatment of the cells as well as the measurement of the monovalent cations was as described in METHODS. Presented are means \pm SD of six determinations using different preparations of the particular cells.

\section{DISCUSSION}

Blood cells represent valuable tissue compartments which can be used to study a wide range of biochemical interactions. In view of the lack of other easily accessible cellular preparations from humans, the convenient availability of blood cells offers the opportunity to use these cells as models to gain information on biochemical processes localized in tissues, which are not readily accessible in man. Most of the available methods for the separation of blood cells are focusing on a particular cell type. Furthermore, because of the low peripheral leukocyte count, the existing procedures frequently require considerab?e amounts of blood. The method described in this study allows the isolation of the three major cell types from a single, small sample of both human and rat blood. The separation is completed in 1.5 to 2 hours and does not require sophisticated instrumentation: a water bath and a table-top centrifuge capable of delivering $2000 \mathrm{~g}$, placed in a cold room $\left(4^{\circ}\right)$, is sufficient. The individual cellular fractions showed a cross contamination of less than $3 \%$ and the obtained yields for leukocytes and platelets of both human and rat blood ranged from 42 to $59 \%$. The purity of the fractions and the cell counts were established both visually and electronically. In view of difficult preferences in expressing biochemical findings, a cor- 


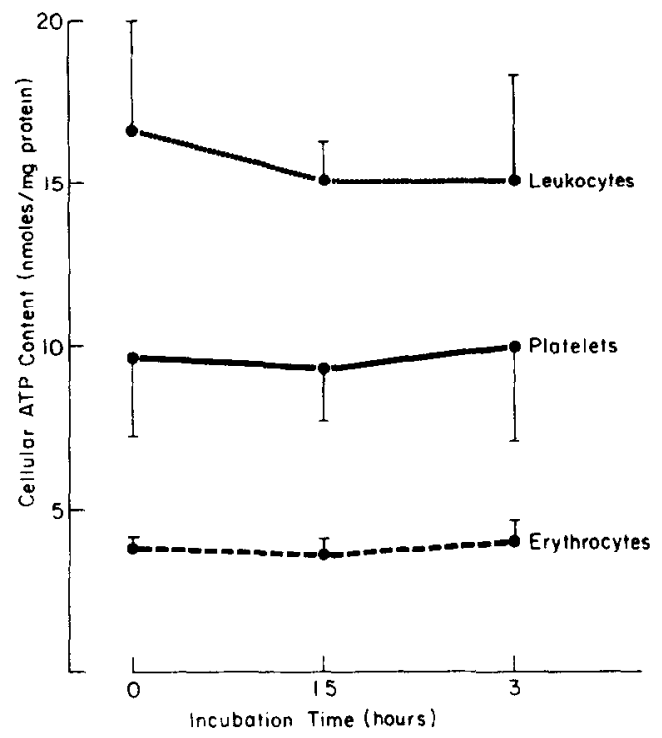

Frc. 6. ATP concentration in human blood cells. Aliquots of the cellular suspensions corresponding to approximately $5 \times 10^{7}$ cells $/ \mathrm{ml}$ of standard incubation medium were incubated at $37^{\circ}$. At the times indicated the tubes were placed in ice. The further treatment of the cells as well as the determination of ATP was as described in METHODS. Presented are the mcans \pm SD of six determinations using separat: preparations of the particular cells.

relation of cell counts with the procein content was provided. An attempt to correlate various reported b:ochemical parameters of blood cells creates considerable difficulties. In expressing their results individual authors vary, in using as a reference, between wet and dry weight, volume of freshly packed cells, volume of intracellular water, as well as cell count. On the other hand, cellular protein content can be estimated by precise chemical determination and, if coupled with cell count, provides a co:avenient and markedly reproducible reference for expressing data of biochemical investigations in blood cells.

Particular importance in this study was given to investigate the viability and metabolic state of the cells immediately after the isolation and during a prolonged incubation at $37^{\circ}$. The selected 3-hour incubation period should allow a variety of in vitro experiments to be carried out. It should be emphasized that, from the beginning of isolation to the end of incubation, the cells were actually 4.5 to 5 hours under in vitro conditions. As an indicator of the integrity of the plasma membrane, the cellular contents of sodium and potassium were estimated. In addition, the exclusion of Trypan Blue was used to ascertain cellular integrity. The 


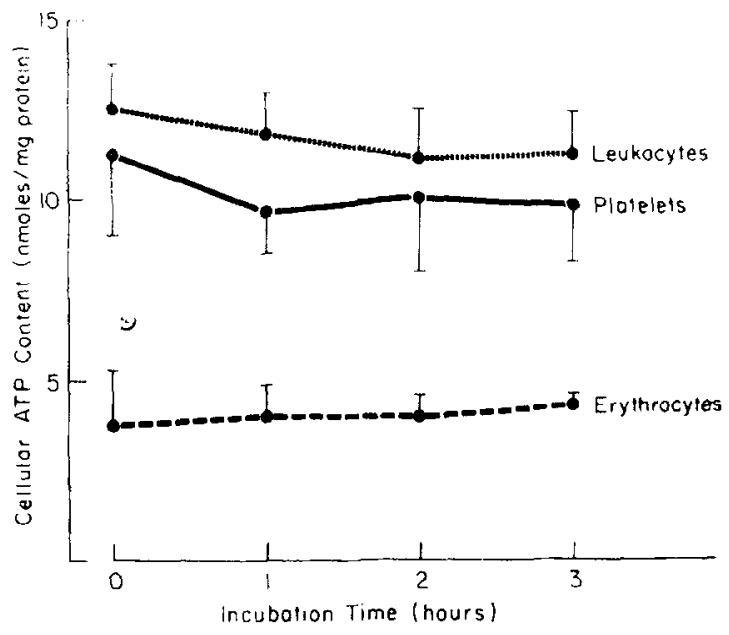

Fig. 7. ATP concentration in rat blood cells. Aliquots of the cellular suspensions corresponding to approximately $5 \times 10^{7}$ cells $/ \mathrm{ml}$ of standard incubation medium were incubated at $37^{\circ}$. At the times indicated the tubes were placed in ice. The further treatment of the cells as well as the determination of ATP was as described in METHODS. Presented are the means \pm SD of six determinations using separate preparations of the particular cells.

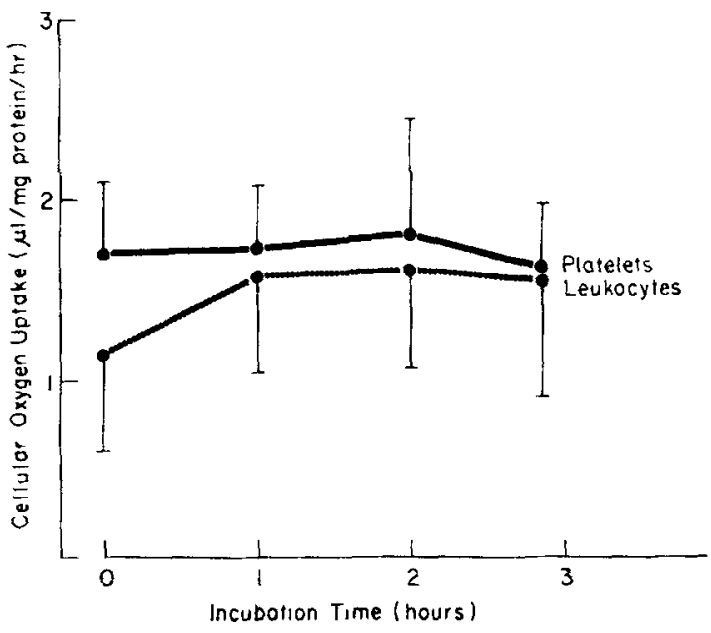

FIG. 8. Oxygen uptake of human cells. Suspensions of freshly isolated cells $\left(1-5 \times 10^{\gamma} / \mathrm{ml}\right)$ were incubated at $37^{\circ}$ in the standard incubation medium. At the indicated times the rate of oxygen uptake of these cellular suspensions was determined as described in METHODS. The results represent means \pm SD of six separate measurements using fifferent preparations of the particular cells. 


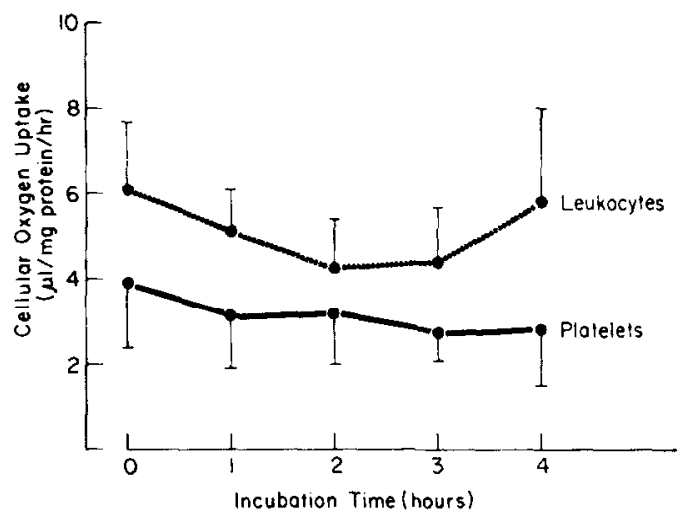

FIG. 9. Oxygen uptake of rat blood cells. Suspensions of freshly isolated cells (1-5 $\times 10^{\%} / \mathrm{ml}$ ) were incubated at $37^{\circ}$ in the standard incubation medium. At the indicated times the rate of oxygen uptake of these cellular suspensions was determined as described in METHODS. The results represent means $\pm \mathrm{SD}$ of six separate measurements using different preparations of the particular cells.

energetic state of the cells was studied by determining the concentrations of ATP. Furthermore, the metabolic capacity was investigated by measuring the oxygen consumption of the cellular suspensions. The latter parameter was found to be a sensitive indicator of cellular viability, whereas vital staining of leukocytes occurred at a later stage of membrane damage (21).

Only limited data are available concerning the here investigated parameters in blood cells of the rat, e.g., the oxygen uptake of rat lymphocytes was reported to be $5 \mu \mathrm{l} / 10^{7}$ cells/hour (22). The corresponding value for rat leukocytes in our study was $3.6 \mu \mathrm{l} / 10^{-}$cells/hour (Fig. 9). Pertinent information for human blood cells is available in the literature, although there is, to our knowledge, no study in which all the here-presented parameters were investigated in one and/or more types of blood cells. Furthermore, even in studies directed specifically towards isolation and characterization of a particular blood cell, e.g., leukocyte (1), the changes of cellular characteristics during a subsequent incubation period were not investigated.

Using sedimentation techniques to isolate human leukocytes, average yields of $24-45 \%$ were reported $(1,5,6)$. In these studies, experiments on Trypan Blue exclusion resulted in $5 \%$ stained cells.

Cellular sodium and potassium contents of human blood cells were reported as (in $\mathrm{nEq} / \mathrm{mg}$ protein, calculated from the originally presented expressions $)$ : erythrocytes, 35 and 250 (23-25); leukocytes, 90 and 300 (26); platelets, 83 and 230 (27). It should be noted that due 
to the necessary use of various conversion factors to allow a compurison of the reported data, the accuracy of the values calculated above inevitably suffered. Changes in leukocyte sodium and potassium during incubation at $37^{\circ}$ were measured by Rosenberg and Downing (5). During 45-minutes incubation at $37^{\circ}$ the ratio of cellular sodium/potassium gradually decreased, indicating a recovery of the initially impaired transmembrane distribution of these ions. The increase, in our study, of sodium and loss of cellular potassium in human leukocytes after 2 hours of incubation (Fig. 4) seems to be the result of the rather high concentrations of EDTA during the separation procedure. On the other hand, lowering the concentration of this compound resulted in impaired separation of the cellular fractions. Owing to the limited extent of this change in cellular ion content and because of the fact that it only occurred after the second hour of incubation, no correcting attempts were made. In rat leukocytes, separated in the absence of EDTA, the ratio cellular sodium/cellular potassium remained constant over the entire incubation period. Pertoft et al. (12) reported, that in order to preserve cell functions of blood cells separated by density gradient centrifugation, the presence of sulfhydryl compounds was essential.

Our results of ATP determinations in human blood cells are within the concentration ranges of this nucleotide reported in the literature (in nmoles $/ \mathrm{mg}$ protein, calculated from the originally presented expressions ): in erythrocytes, $3.5-4,(29-31)$ and in platelets, 7-8.5, (32, 33). In human leukocytes, the measured ATP content was lower than the 51 nmoles $/ 10^{7}$ cells reported by Frei (30). Other corresponding data, summarized by Seitz (34), are not unequivocal due to the diverse expression of results. In earlier studies, data for ATP levels in biological material were often too high due to a lack in specificity of the analytical procedure.

Finally, the rate of oxygen uptake of human leukocytes and platelets correlates favorably with the following reportcd values for the respiration of these cells (in $\mu \mathrm{l} \mathrm{O}_{z} / \mathrm{mg}$ protein, calculated from the originally presented expressions ): 1.7 (1) and 1.5 (27), respectively.

In addition to the favorable correlation of the determined parameters with corresponding reported data, it is of particular significance to emphasize the constancy of these parameters in our cellular preparations during a prolonged incubation at $37^{\circ}$. These findings suggest, that during a 3-hour incubation period following the isolation, the integrity of the plasma membrane, the energetic state, and metabolic capacity of these cells remained unchanged. This manyfold proven viability, together with the simplicity of the isolation of the highly pure fractions of various cells from a single small sample of blood, should contribute to the labo- 
ratory investigation of these valuable tissue compartments. Additional versatility is provided by presenting data for both human and rat blood cells.

\section{SUMMARY}

A simple procedure is presented for the isolation of erythrocytes, leukocytes and platelets from single small samples of both human and rat blood. The separation of cells is based on sedimentation and lowspeed centrifugation. The obtained yields for the various cells ranged from $42-85 \%$. The cross contamination of the individual cellular fractions was less than $5 \%$. The purity of the cellular fraction was ascertained by microscopic examination and electronic size distribution. Cellular viability, energetic state, and metabolic function was investigated by Trypan Blue exclusion, by determination of cellular contents of sodium, potassium, and ATP, as well as by measurements of oxygen consumption. The obtained data compared favorably with those reported previously and the investigated parameters remained essentially constant over a 3-hour incubation period at $37^{\circ}$.

\section{ACKNOWLEDGMENT}

This work was supported in part by USPHS Grant Nos. 2P11 GM15559 and R01DA-00254.

\section{REFERENCES}

1. Fallon, H. J., Fret, E., III, Davinson, J. D., Trieh, J. S., and Burk, D., J. Lab. Clin. Med. 59, 779 (1962).

2. Christlieb, A. R., Sbahra, A. J., and Bardawil, W. A., Amer. J. Clin. Pathol. 37, 257 (1962).

3. Boyum, A., Nature (London) 204, 793 (1964).

4. Coulson, A. S., and Chalmers, D. G., Lancet 1, 468 (1964).

5. Rosenberg, L. E., and Downing, S., J. Clin. Invest. 44, 1382 (1965),

6. Baron, D. N., ANd Ammed, S. A., Clin. Sci. 37, 505 (1969).

7. BaEhner, R. L., Gilman, N., ANd Kariovsky, M. L., J. Clin. Invest. 49, 692 (1970).

8. Leise, E. M., Morita, T. N,, Gray, I., and LeSane, F., Biochem. Med. 4, 327 (1970).

9. Karpatkin, S., J. Clin. Invest. 48, 1073 (1S69).

10. Zieve, P. D., Solomon, H. M., and Krevans, J. R., J. Cell. Comp. Physiol. 67, 271 (1966).

11. Freireich, E. J., Judson, G., ANd Levin, R. H., Canc $r$ Res. 25, 1516 ( 1965 ).

12. Pertoft, H., Back, O., ani) Lindahi-Kiessling, K., Exp. Cell Res. 50, 355 (1968).

13. Brubaker, L. H., and Evans, W. H., J. Lab. Clin. Med. 73, 1036 (1969).

14. Medzihradsky, F., Marks, J. M., and Cark, E. A., Jr., Biochem. Pharmacol. 21, 1625 (1972).

15. Marks, J. M., AND Medzihradskx, F., Abstract No. 891, Abstracts of Volunteer 
Papers, 5th Internat. Congr. Pharmacol., San Francisco, 1972.

16. Medzihradsky, F., Marks, M. J., and Metcalfe, J. I., Adtan. Biochem. Psychopharmacol. 8, 537 (1974).

17. Cartwright, G. E., "Diagnostic Laboratory Hemulology," th Ed., Chap. 9. Grune and Stratton, New York, 1968.

18. Melamei, M. R., Kamenisky, L. A., and Boyse, E. A., Science 163, 285 (1969).

19. Melamed, M. R., Adams, L. R., Zimring, A., Murnick, J. G., and Mayer, K., Amer. J. Clin. Pathol. 57, 95 (1972).

20. Lowhy, O. H., Rosebrougi, N. J., Farr, A. L.. and Randall, R. J., I. Biol. Chem. 193, 265 ( 1951 ).

21. Tullis, J. L., Blood 8, 563 (1953).

22. Cooper, E. H., and Fitzgerald, M. G., Biochem. J. 68, 5 (1958).

23. Overman, R. R., and David, A. K., J. Biol. Chem. 168, 641 (1947).

24. Widdowson, E. M., and McCance, R. A., Clin. Sci. 15, 361 (1956).

25. McCance, R. A., And Widdowson, E. M., Clin. Sci. 15, 409 (1956).

26. Baron, D. N., and Rorerts, P. M., J. Physiol. 165, 219 (1963).

27. Markus, A. J., ANd Zucker, M. B., "The Physiology of Blood Platelets." Grune and Stratton, New York, 1965.

28. Mandel, P., and Chambou, P., Bull. Soc. Ch:m. Biol. 41, 989 (1959).

29. OvergaAnd-Hansen, K., and Jorgensen, S., Scand. J. Clin. Lab. Invest. 12, 10 (1960).

30. FrEI, J., in "Biological Activity of the Leukocyte" (G. E. W. Wolstenholme and M. O'Connor, Eds.), p. 86. Ciba Found. Study Group No. 10. Little, Brown and Co., Boston, Mass., 1961.

31. Feig, S. A., Shohet, S. B., and Nathan, D. G., J. Clin. Invest. 50, 1731 ( 1971 ).

32. Bettex-Galland, M., and Lüscher, E. F., Nature (London) 184, 276 (1959).

33. Gross, R., and Schneider, W., in "The Circulating Platelet," (Sh. A. Johnson, Ed.), p. 123. Academic Press, New York, 1971.

34. SEITZ, J. F., "The Biochemistry of The Cells of Blood and Bone Marrow," p. 50. Ch. C. Thomas, Springficld, IIl., 1969. 